\title{
Análise do polimorfismo dos genes CYP17, GSTM1 e receptor de progesterona (PROGINS) e sua relação com a determinação da densidade mamária em mulheres após a menopausa sem terapia hormonal
}

\section{Study of CYP17, GSTM1 and progesterone receptor (PROGINS) genes polymorphism and mammographic density in postmenopausal women without hormonal therapy}

Autor: Danielle Chambô

Orientador: Prof. Dr Cláudio Kemp

Co-orientador: Prof. Dr Ismael Dale Cotrim Guerreiro da Silva

Tese apresentada à Universidade Federal de São Paulo - Escola Paulista de Medicina, para obtenção do Título de Mestre em Ciências, em 9 de fevereiro de 2006

Introdução: a densidade mamográfica é um dos fatores preditivos para o risco de câncer de mama e sua extensão está diretamente relacionada com o estado pós-menopáusico. No entanto, algumas pacientes permanecem com mamas densas, mesmo na menopausa. Esta condição pode ter sua explicação em bases genéticas. Os genes que codificam as proteínas envolvidas na biossíntese, ação e metabolização dos hormônios esteróides são polimórficos, o que pode explicar as variações individuais do nivel hormonal e conseqüentemente da densidade mamária. A constante necessidade de se buscar marcadores que possam auxiliar na prevenção primária do câncer de mama e na seleção de pacientes de alto risco (densidade mamária determinada pela individualidade genética humana) incentivaramnos a realizar este estudo. Objetivos: analisar a presença de polimorfismo dos genes CYP17 (gene que codifica a enzima citocromo p450 $\propto 17$ - responsável pela biossintese dos esteróides DHEA e androstenediona), GSTM1 (responsável pela metabolização de esteróides sexuais) e receptores de progesterona (PROGINS) e sua relação com a determinação do padrão mamográfico. Métodos: foram incluídas 123 pacientes na pós-menopausa, não usuárias de terapia hormonal e sem alterações mamárias (clínicas ou mamográficas). Todas foram submetidas a mamografia bilateral e a densidade mamária foi determinada por dois observadores independentes, de acordo com o sistema ACR-BI-RADS ${ }^{\circledR} 2003$. Para se obter o valor absoluto de densidade as mamografias foram digitalizadas e a densidade calculada por meio do histograma de escala de cinza do software ADOBE PHOTOSHOP ${ }^{\circledR}$ 6.0. Amostras de raspado bucal foram obtidas para extração do DNA, a qual foi realizada segundo protocolo do KIT GFX ${ }^{\circledR}$. Após extração do DNA, a PCR-RFLP (reação de cadeia de polimerase restricton fragment length polymorphism) foi realizada para análise do polimorfismo do CYP17, GSTM1 e receptor de progesterona. Resultados: a determinação da densidade mamária (densa e não densa) entre os observadores foi Kappa $=1$ (perfeita) e, entre observadores e Photoshop ${ }^{\circledR}$, Kappa $=0,93$, o que mostra ser o método reprodutivel. Não houve associação entre mama densa e CYP17 (p = 0,18) ou com GSTM1 $(p=0,425)$. O PROGINS revela tendência à significância $(p=0,084)$. Dentre as variáveis analisadas foi relevante o índice de massa corpórea $(\mathrm{p}<0,001)$, a paridade $(\mathrm{p}=0,007)$ e a idade da menarca $(\mathrm{p}=0,003)$. Utilizando o modelo de regressão logística multivariado, obtivemos valor de $\mathrm{p}=$ 0,030 para pacientes com o seguinte perfil genético: PROGINS selvagem e CYP17 mutado. Conclusões: o polimorfismo dos genes CYP17 e GSTM1 não apresentou relação com a densidade mamográfica quando analisado isoladamente. O polimorfismo do receptor de progesterona (PROGINS) mostrou tendência em relação às mamas densas. Este resultado deve-se, provavelmente, ao tamanho da amostra, em face da mutação não tão freqüente. No entanto, pacientes que apresentam associação de PROGINS selvagem e CYP17 mutado têm 4,87 vezes maior chance de terem mamas densas do que as sem este perfil genético.

PALAVRAS-CHAVE: Mamografia; Polimorfismo (genética); Esteróide 17-alfa-hidrolase; Glutationa transferase; Receptores de progesterona 